\title{
THE REVERSION OF HARDENING PROCESS AND HYDROGEL USE IN A 4 FOREST SPECIES PLANTATION
}

Rafaella Carvalho Mayrinck ${ }^{1}$, Ximena Mendes de Oliveira ${ }^{1}$, Vinicius Gontijo Rodrigues Roque ${ }^{2}$, Janice Ferreira do Nascimento ${ }^{3}$, Lucas Amaral de Melo ${ }^{4}$

${ }^{1}$ Mestranda em Engenharia Florestal pela Universidade Federal de Lavras (rafamka@hotmail.com), Lavras-MG, Brasil

${ }^{2}$ Mestrando em Genética e Melhoramento de Plantas pela Universidade Federal de Lavras, Lavras-MG, Brasil

${ }^{3}$ Profa Dra do Instituto Federal de Rondônia, Vilhena-Rondônia, Brasil

${ }^{4}$ Prof. Dr. do Departamento de Engenharia Florestal da Universidade Federal de Lavras, Lavras-MG, Brasil

Recebido em: 08/04/2017 - Aprovado em: 10/06/2017 - Publicado em: 20/06/2017 DOI: 10.18677/EnciBio_2017A98

\begin{abstract}
The aim of this study was to evaluate the effects of hydrogel on the number of irrigation, initial growth and survival of hardened seedlings and seedlings which the hardened condition was reverted, called hereafter by unhardened seedlings. The seedlings (Psidium guajava, Anadenanthera colubrina, Inga vera, and Lonchocarpus cultratus) were planted on the field, with or without hydrogel in the planting hole. The experiment was conducted in randomized blocks, arranged in a factorial scheme of 4 $\times 2 \times 2$ (four forest species; two conditions of the seedlings - hardened and unhardened; and two planting conditions - with or without hydrogel). After planting, a treatment was irrigated when most of the plants in that treatment had symptoms of temporary wilting. The parameters evaluated were the number of irrigations performed, stem diameter growth, and seedling survival. It was concluded that the addition of hydrogel and the unhardening process in the planting hole helped in reducing the number of irrigations required.
\end{abstract}

KEYWORDS: irrigation, native species, reforest, temporary wilt.

\section{REVERSÃO DO PROCESSO DE RUSTIFICAÇÃO E USO DE HIDRÓGEL EM UMA PLANTAÇÃO DE QUATRO ESPÉCIES FLORESTAIS}

\section{RESUMO}

Este trabalho objetivou avaliar o efeito do hidrogel no plantio sobre o número de irrigações, o crescimento inicial e a sobrevivência de mudas de espécies arbóreas submetidas ou não ao tratamento de desmumificação. Mudas mumificadas e desmumificadas de Psidium guajava, Anadenanthera colubrina, Inga vera, e Lonchocarpus cultratus foram plantadas em campo com ou sem a aplicação de hidrogel na cova de plantio. O experimento foi realizado em campo e instalado em blocos casualizados, disposto no esquema fatorial $4 \times 2 \times 2$ (quatro espécies florestais; duas condições das mudas - mumificadas ou desmumificadas; e duas 
condições de plantio - com hidrogel ou sem hidrogel). Depois do plantio, as irrigações eram realizadas quando a maioria das plantas de um tratamento apresentava sintomas de murcha temporária. Os parâmetros avaliados foram o número de irrigações realizadas, o diâmetro do coleto e a sobrevivência das mudas. Concluiu-se que a adição do gel e a desrustificação contribuíram para diminuir o número de irrigações efetuadas.

PALAVRAS-CHAVE: espécies nativas, irrigação, murcha temporária, reflorestamento.

\section{INTRODUCTION}

Some causes of failure in forest implementation for recovering ecosystems are soil moisture deficiencies, desiccation of roots caused by direct contact with fertilizer, competition with weeds and attack of cutting ants (KRAG et al., 2013). The lack of water usually occurs due to planting in the dry season and or by the occasional occurrence of dry hot periods during the rainy season, which increases the percentage of mortality in seedlings.

Water is the most limiting factor for seedlings establishment and growing on field (DIAS-TERCEIRO et al., 2014). Although irrigating is an expensive activity, it is necessary in an array of situations (FELIPPE et al., 2016). The possibility to install plantations for forest recovering during the dry season carry some advantages within, such as: the ease weed control, availability of staff to work on it, and besides that, nurseries can sell seedlings all over the year, what promotes a positive impact on local economy.

To reduce the effects of lack of water at planting during the dry season, the hydrogel has been used because it is able to retain water and to provide humidity gradually for newly planted trees, increasing water storage in the soil, as an alternative to situations where soil moisture is low (BARBOSA et al., 2013; AZEVEDO et al., 2016).

Hydrogels have been used in planting crops since the 60s, improving physical and chemical properties of the soil, making it possible to reduce the number of irrigations and consequently reducing costs in growing crops (DRANSK et al., 2013; MARQUES et al., 2013, FELIPPE et al., 2016). The hydrogel, when dry, is composed by small granules, which in contact with water, absorb it, breaking the links between the polymers molecules, which expands turning into a transparent gelatinous agglomerate and highly hydrate, which can hold 100 to 300 times its dry weight in water (MONTESANO et al., 2015; NAVROSKI et al., 2016). However, there are few studies that verify the feasibility and effectiveness of hydrogels in implementing native species forests (FRÓES et al., 2014; MEWS et al, 2015; NAVROSKI et al., 2016).

In addition to soil moisture at planting, the degree of hardening of the seedlings is a factor that may also contribute to seedlings surviving in the field (MAZZUCHELLI et al., 2014). The hardening process is made by synchronizing root pruning and increasing the gap between irrigations, in order to reach osmotic adjustment of seedlings (D'AVILA et al., 2011). The reduction of nitrogen fertilization and the maintenance or increase of potassic fertilization also assists in this process (SILVEIRA \& MALAVOLTA, 2000; D'AVILA et al., 2011) highlighted the importance of potassium $(\mathrm{K})$ during the seedling production phase, reporting that well-nourished 
plants with this nutrient are more resistant to drought and frost, due to increasing of water retention in the tissues.

Age may also influence the degree of hardening when the seedlings are grown in containers with reduced volume capacity (MAFIA et al., 2005). As the seedlings age, remaining for too long in the nursery through the hardening process, they may present symptoms of mummification. This is because the seedlings reduce its vegetative growth, no longer emit new roots, close its stomata and enter a dormant period. In the field, mummified seedlings usually have higher potential for survival, whereas their growth rates are reduced.

Thus, this study aimed to evaluate the effect of the use of hydrogel in hardened and unhardened seedlings of four native tree species (Psidium guajava, anadenanthera colubrina, Inga vera, and Lonchocarpus cultratus).

\section{MATERIALS AND METHODS}

For this study, seedlings of Psidium guajava (Linn) (goiaba), Anadenanthera colubrina (Vell.) (angico vermelho), Inga vera (Wild) (ingá), and Lonchocarpus cultratus (Vell) (embira de sapo) were used. All are commonly used in reforest programs (NOGUEIRA JUNIOR et al., 2014; GOÉS \& QUINTELA, 2015; GAGETTI et al., 2016; KORTZ et al., 2014).

The seedlings were produced in June, using $115 \mathrm{~cm}^{3}$ containers, at the forest nursery at Universidade Federal de Lavras (UFLA). The substrate used was composed by $10 \%$ subsoil, $40 \%$ cow manure and $50 \%$ carbonized rice husk. As basic fertilization, $4 \mathrm{~kg}$ of slow-release (six monhs) fertilizer (Osmocote®) (15:09:12 $\mathrm{NPK}+\mathrm{Ca}, \mathrm{Mg}$ and micronutrients) per $\mathrm{m}^{3}$ of substrate was used. The containers were placed on suspended trays exposed to sunlight and three daily irrigations through the automatic nursery sprinkler system.

All the essential practices to obtain seedlings of high quality were performed, from sowing until the hardening process. The hardening process was initiated when the seedlings were five months old, and lasted for thirty-five days, passing through gradual reduction of irrigation, lack of nitrogen dressing and maintenance of potassic fertilizers $(0.015 \mathrm{~g}$ of potassium chloride per seedling, diluted in $10 \mathrm{ml}$ of water, weekly).

After the hardening process was concluded, 11 months after sowing, half the seedling of each specie was subjected to a topdressing process in order to unharden seedlings. Fertilization was performed weekly for five consecutive weeks, with a solution of $200 \mathrm{~g}$ of ammonium sulfate and $150 \mathrm{~g}$ of potassium chloride diluted in 100 liters of water, as recommended by GONÇALVES et al. (2000). Each seedling received $10 \mathrm{~mL}$ of this solution weekly using a syringe graduated in milliliters.

Next, an experiment was conducted on the field in dry season at Universidade Federal de Lavras, in Lavras, Minas Gerais. The experiment was conducted between June and December, in a Red Latossoil (RAMOS et al., 2013). According to the Köppen climate classification, the regional climate is Cwa Lavras with characteristic Cwb, presenting two distinct seasons: dry from April to September and rainy from October to March (ALVARES et al., 2013). The soil in the planting area was harrowed and furrowed $25 \mathrm{~cm}$ deep and the planting hole was $25 \times 25 \times 25 \mathrm{~cm}$. The spacing was $1.5 \mathrm{~m} \times 1.0 \mathrm{~m}$. In each planning hole was added $50 \mathrm{~g}$ of superphosphate. 
The experiment was installed in randomized blocks, arranged in a factorial $4 \mathrm{x}$ $2 \times 2$ (four forest species, two conditions of seedlings - hardened or unhardened, and two planting conditions hydrogel -with or without hydrogel), totaling 16 treatments, arranged in four blocks and linear plot with eight plants each.

The hydrogel used was STOCKOSORBA, manufactured by Huls Inc. Degussa, made of polymers formed of acrylamide (acrylic acid based on potassium salt). The hydrogel was hydrated for 24 hours (EVANS \& BOWMAN, 1991) and applied to the hole planting at a rate of $1.5 \mathrm{~g}$ of hydrogel contained in $300 \mathrm{ml}$ of solution (BUZETTO et al., 2002), homogenized with soil in the planting hole. The seedlings were planted in the center of each planting hole and immediately after planting, all received five liters of water. Temperature, air relative humidity and rainfall values were obtained from the meteorological station (Figure 1), located at UFLA, $500 \mathrm{~m}$ from the experimental area.

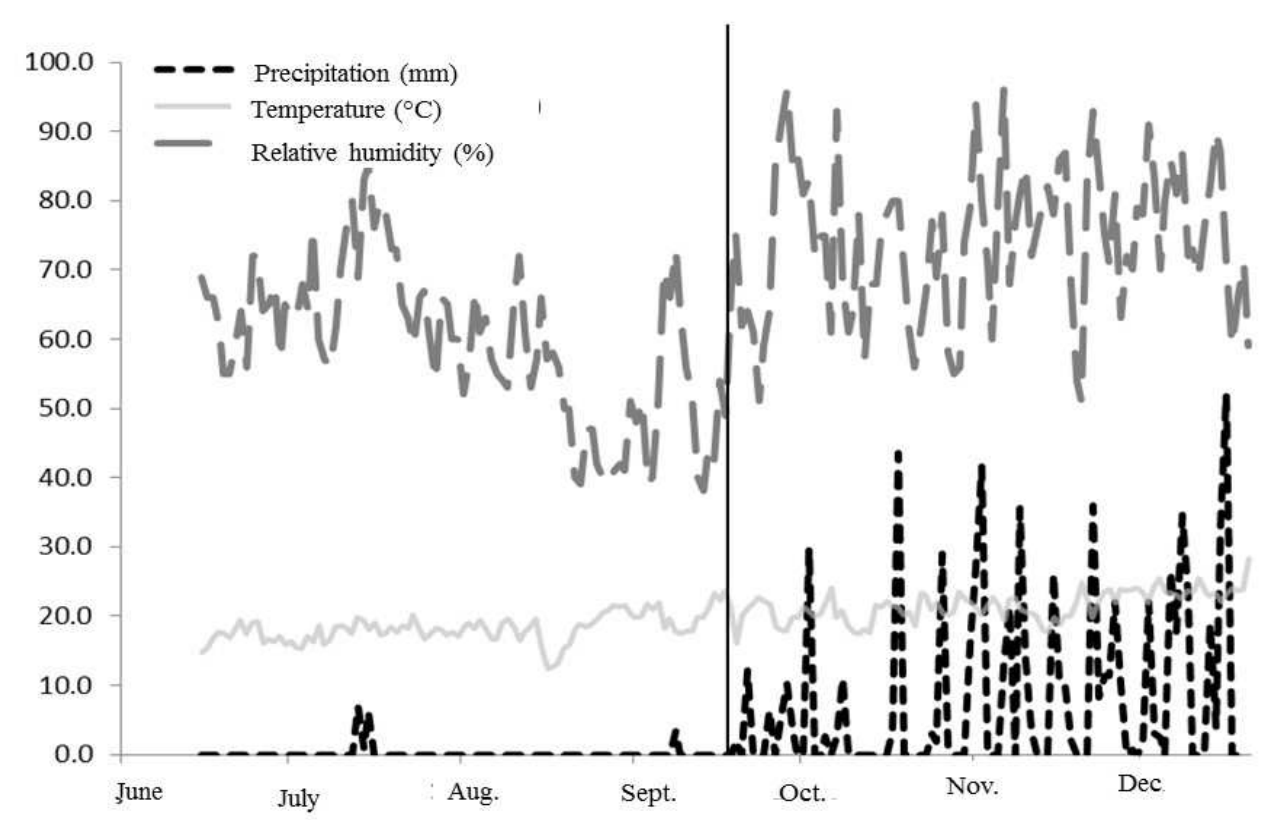

FIGURE 1 - Precipitation $(\mathrm{mm})$, average temperature $\left({ }^{\circ} \mathrm{C}\right)$, and relative humidity \%, at Lavras, MG. The vertical line refers to the end of the period of irrigation, as the rainy season started.

After planting in the field, the plants were monitored and when most of plants in a plot had visual symptoms of temporary wilting, the plot was irrigated with three liters of water. Thus, the number of irrigations made during the trial period was recorded for each plot. The irrigations were suspended at the end of September (88 days after planting in the field), with the onset of the rains (Figure 1), when all the plants received 30 grams of fertilizer N: P: K (20:00:20).

During the trial period diameter measurements were carried out fortnightly, during the first three months after planting and monthly thereafter until the end of the experimental period (200 days after planting in the field). The stem diameter was measured using calipers $0.05 \mathrm{~mm}$ accurate. The percentage of survival of seedlings was assessed at the end of the trial period. 
Data were submitted to analysis of variance (ANOVA) and when verified significant differences $(p>0.05)$, the mean was assessed by Tukey test at $5 \%$ probability. The graphs and equations were generated using the Sigmaplot $11.0 \AA$ software.

\section{RESULTS AND DISCUSSION}

\section{Number of irrigation in seedlings of four forest tree species}

It was found that for all species studied, the hydrogel contributed to substantial savings in irrigation over the 88 days of trial period, and generally the unhardening process also had an important role in reducing the need for irrigation (Figure 2). Similar results were found by NAVROSKI et al. (2014) were hydrogel reduced the number of irrigation and raise plant survival.
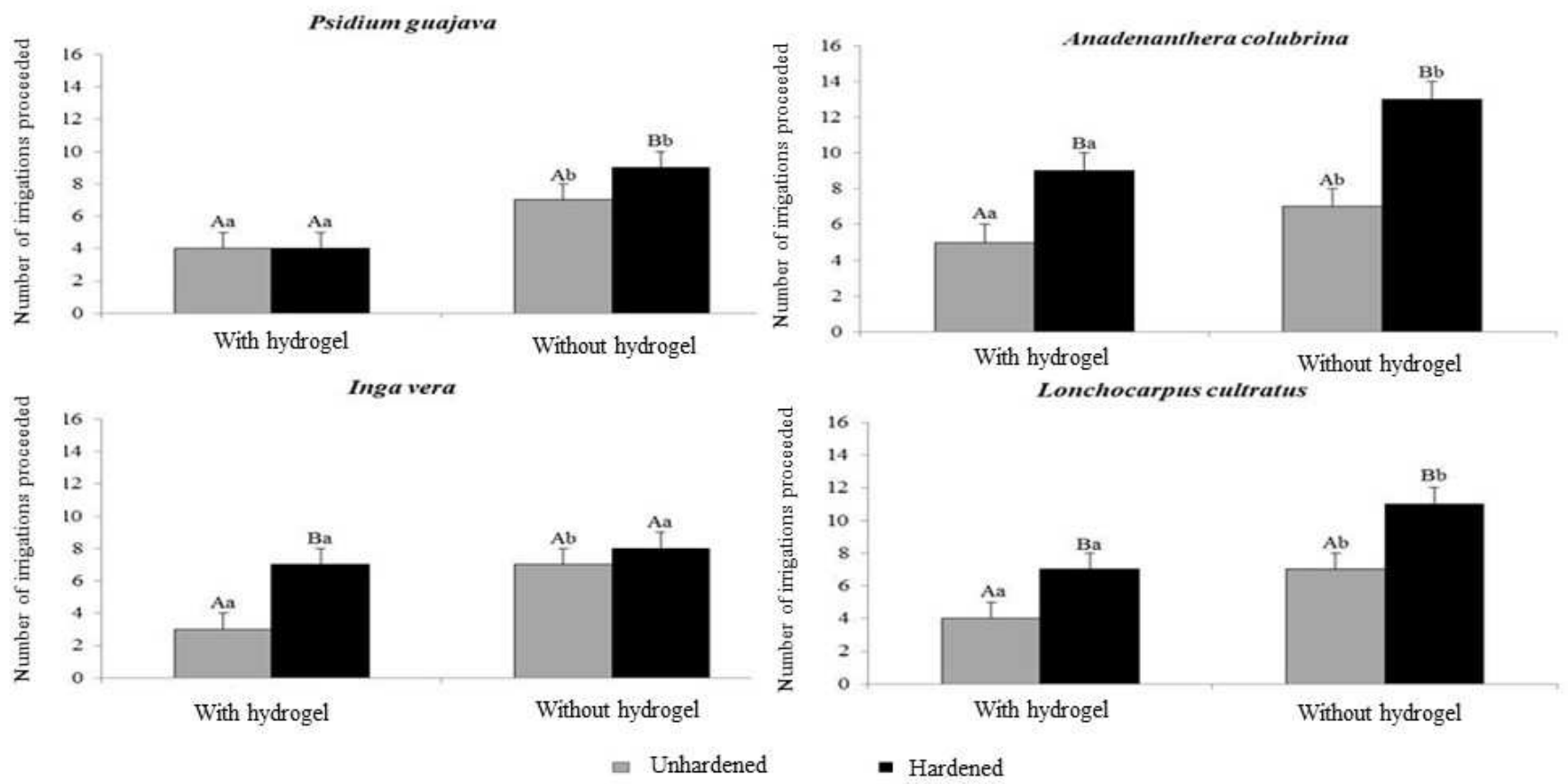

FIGURE 2 - Total number of irrigations proceeded in seedlings of $P$. guajava, A. colubrina, I. vera, e L. cultratus during 88 days of trial. In each specie, means with the same letter have no meaningful difference, according to the Tukey test at $5 \%$ of probability. Capital letters compare hardening levels and small letters compare hydrogel levels.

For seedlings of $P$. guajava, planted without hydrogel, the unhardening process reduced the need for irrigation from nine to seven irrigations during the trial period in the field. Using hydrogel, the plants needed 4 irrigations, no matter if the seedlings were hardened or not. For A. colubrina, it is clear that the unhardening process caused a pronounced decrease in the need for irrigation. Unhardened seedlings planted or not with hydrogel needed to be irrigated five and seven times, respectively, while hardened seedlings demanded nine and thirteen irrigations, with and without hydrogel at planting hole, respectively.

Less need for irrigation was observed in unhardened seedlings of I. vera planted with addition of hydrogel, which required only three irrigations during the 88 
days (Figure 2). Seedlings of the same species, with the addition of hydrogel, but hardened, had to be irrigated seven times, the same way, seedlings without the application of hydrogel but unhardened demanded 7 irrigations as well. Unhardened seedlings planted without hydrogel were watered 8 times.

Unhardened seedlings of $L$. cultratus planted without hydrogel were irrigated on seven occasions, while hardened seedlings demanded eleven irrigations. Likewise, seedlings planted with hydrogel, but hardened required seven irrigations while the seedlings planted with hydrogel and unhardened were irrigated only four times. For species I. vera and L. cultratus, observed similar results with respect to the required number of irrigations in hardened seedlings planted with hydrogel and unhardened planted without hydrogel (Figure 2).

One of the disadvantages of using hardened seedlings is that these plants exhibit inactive root system, which is easily visualized, in practice, by the absence of living roots with white, yellow or purple, depending on species. Planting seedlings with this aspect can delay the development of the forest, because the seedlings will have more difficulties in expanding its root system, since it is necessary, first, to develop new roots and then begin to grow. In the other hand, planting seedlings with active root system (unhardened), even without the application of hydrogel may require the same amount of water of those seedlings planted hardened planted with hydrogel. This equivalence between seedlings that pass through the unhardening process and those ones planted with hydrogels can be attributed to the activation of plant roots by unhardening process, activity that leads to the formation of new roots in the nursery stage, allowing the absorption of water more efficiently in the field by rapid expansion the root system by exploiting a larger volume of soil in shorter time.

FREITAS et al. (2005) stated that seedling of good quality, robust and with greater new roots emission are better able to withstand environmental stress, increasing survival rates in the field. However smaller seedlings with root deformations due to restrictions in the production phase in the nursery may delay or reduce growth in its implementation in the field, resulting in higher costs with weed control and delaying the expected growth.

$P$. guajava was the only specie in which, under application of hydrogel, there was no difference in the number of irrigations between hardened and unhardened seedlings. This result can be explained by observations in the field, where the unhardened seedlings emitted new leaves, due to the response to coverage fertilizations (part of the unhardening process), wilted more easily than hardened seedlings. When planted, these seedlings demanded initially, more irrigations. Still, it took only four irrigations.

In the United States, the Colorado State Forest Service had an increasing in survival rate of seedling with the use of agricultural polymers at the time of transplanting and sowing, besides this practice have accelerated the growth of these plants by greater supply and water availability (WOFFORD JR. \& KOSKI, 1990). ADAMS \& LOCKABY (1987) studied the effect of polymers in forest species plantating and observed that eighteen days after the first irrigation, $100 \%$ of the seedlings withered used as control, while receiving the hydrogel remained turgid.

LOPES et al. (2010) studied the use of hydrogel on survival of clonal plants of a hybrid between $E$. grandis and Eucalyptus urophylla, produced with different substrates and water management and observed that plants with hydrogel had 
symptoms of lack of water delayed and this exerted influence on the survival, providing 37 days without the need for additional irrigation.

\section{Steam diameter of four forest seedlings}

Regarding the growth of seedlings, when analyzing the stem diameter, the treatments did not differ (Figure 3), both at 88 days after planning (when there was interruption of irrigation due to the onset of the rainy season) and at 200 days, when the trial finished.

The presence or absence of hydrogel did not significantly influence the growth in steam diameter, and this fact can be attributed to watering that plants of treatments without hydrogel received more often than the seedlings of treatment with the hydrogel. A similar result was found by NISSEN \& OVANDO (1999) applying the hydrogel prior to planting Obliqua Nothofagus (the roots were immersed in a $0.5 \%$ solution with hydrogel for 5 to 10 minutes).

Analyzing the growth in diameter of steam of plants, four all species and all treatments, there is an increase in the steepness of the curves, especially between 100 and 150 days after planting (Figure 4), coinciding with the period in which there was the beginning of the rainy season (Figure 1), showing that the availability of water is a determining factor for plant growth. Regarding dry root biomass, wich is related to diameter, NICOLETTI et al. (2014) found that the hydrogel use increased this parameter.
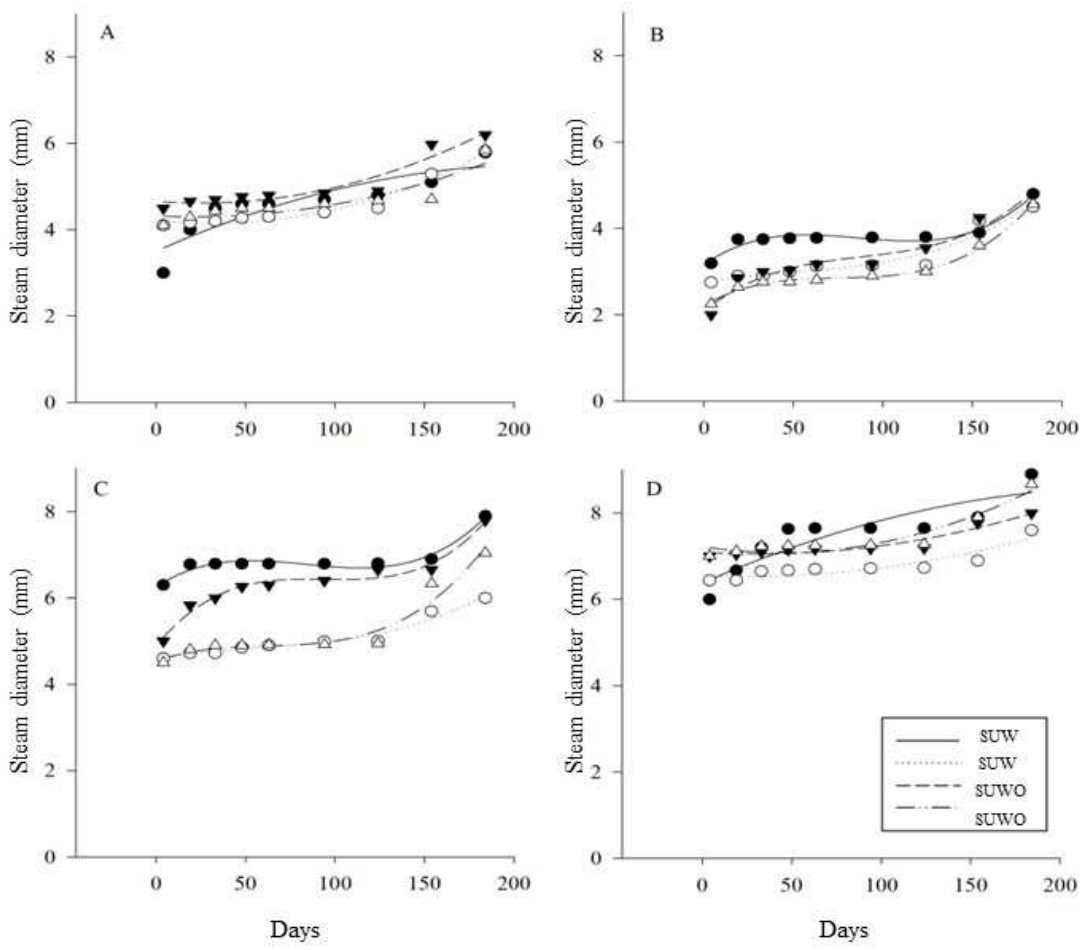

FIGURE 3 - Diameter growth in seedlings of $P$. guajava (A), $A$. colubrina $(B)$, I. vera $(C)$ and $L$. cultratus $(\mathrm{D})$ over time after planting. SUW - seedlings unhardened with hydrogel, SHW - seedlings hardened with hydrogel, SUWO - seedlings unhardened and without hydrogel, and SHWO - seedlings hardened and without hydrogel. 
TABLE 1 - Equations and coefficients of determining for curves related to the increase in diameter over time for seedlings of $P$. guajava, $A$. colubrina, I. vera e $L$. cultratus, depending on hardening and hydrogel use. SD: Steam diameter.

\begin{tabular}{|c|c|c|c|c|}
\hline Specie & $\begin{array}{l}\text { Physiological } \\
\text { condition }\end{array}$ & $\begin{array}{l}\text { Planting } \\
\text { hole }\end{array}$ & Equation & $\mathbf{R}^{2}$ \\
\hline P. guajava & Unhardened & $\begin{array}{l}\text { With } \\
\text { hydrogel }\end{array}$ & $S D=-4,24 x^{2}+0,02 x+3,50$ & 0,79 \\
\hline P. guajava & Hardened & $\begin{array}{l}\text { With } \\
\text { hydrogel }\end{array}$ & $S D=7,17 x^{2}-4,71 x+4,23$ & 0,96 \\
\hline P. guajava & Unhardened & $\begin{array}{l}\text { Without } \\
\text { hydrogel }\end{array}$ & $S D=6,47 x^{2}-3,28 x+4,66$ & 0,91 \\
\hline P. guajava & Hardened & $\begin{array}{l}\text { Without } \\
\text { hydrogel }\end{array}$ & $S D=4,70 x^{2}-2,03 x+4,32$ & 0,79 \\
\hline A.colubrina & Unhardened & $\begin{array}{l}\text { With } \\
\text { hydrogel }\end{array}$ & $S D=1,45 x^{3}-3,77 x^{2}+0,03 x+3,16$ & 0,96 \\
\hline A. colubrina & Hardened & $\begin{array}{l}\text { With } \\
\text { hydrogel }\end{array}$ & $S D=4,96 x^{3}-7,59 x^{2}+7,19 x+2,75$ & 0,93 \\
\hline A. colubrina & Unhardened & $\begin{array}{l}\text { Without } \\
\text { hydrogel }\end{array}$ & $S D=1,21 x^{3}-3,21 x^{2}+0,03 x+2,09$ & 0,95 \\
\hline A. colubrina & Hardened & $\begin{array}{l}\text { Without } \\
\text { hydrogel }\end{array}$ & $S D=1,29 x^{3}-2,93 x^{2}+0,02 x+2,22$ & 0,99 \\
\hline I. vera & Unhardened & $\begin{array}{l}\text { With } \\
\text { hydrogel }\end{array}$ & $S D=1,48 x^{3}-3,72 x^{2}+0,03 x+6,26$ & 0,96 \\
\hline I. vera & Hardened & $\begin{array}{l}\text { With } \\
\text { hydrogel }\end{array}$ & $D C=3,99 x^{3}-6,88 x^{2}+7,12 x+4,59$ & 0,96 \\
\hline I. vera & Unhardened & $\begin{array}{l}\text { Without } \\
\text { hydrogel }\end{array}$ & $S D=1,91 x^{3}-5,39 x^{2}+0,05 x+4,89$ & 0,97 \\
\hline I. vera & Hardened & $\begin{array}{l}\text { Without } \\
\text { hydrogel }\end{array}$ & $S D=1,17 x^{3}-2,17 x^{2}+0,01 x+4,53$ & 0,94 \\
\hline L.cultratus & Unhardened & $\begin{array}{l}\text { With } \\
\text { hydrogel }\end{array}$ & $S D=-3,70 x^{2}+0,02 x+6,35$ & 0,84 \\
\hline L.cultratus & Hardened & $\begin{array}{l}\text { With } \\
\text { hydrogel }\end{array}$ & $S D=3,49 x^{2}-1,74 x+6,55$ & 0,83 \\
\hline L. cultratus & Unhardened & $\begin{array}{l}\text { Without } \\
\text { hydrogel }\end{array}$ & $S D=4,02 x^{2}-2,51 x+7,09$ & 0,92 \\
\hline L. cultratus & Hardened & $\begin{array}{l}\text { Without } \\
\text { hydrogel }\end{array}$ & $S D=7,22 x^{2}-6,28 x+7,22$ & 0,90 \\
\hline
\end{tabular}

\section{Survival of seedlings}

The average survival of seedlings of all four species, after 200 days after sowing was $93 \%$, with no significant differences between treatments (Table 2), which can be attributed to irrigation that the treatments without hydrogel and or hardened plants received more often, compared to plants with hydrogel and unharddened. Probably, if the number of irrigations were the same between treatments, the survival would differ statistically. 
This assumption corroborates the results obtained by THOMAS (2008), in a study that aimed to reduce mortality in Eucalyptus pilularis and Corymbia citriodora. After planting, the author observed that the hydrogel improves the survival of seedlings, allowing the roots to grow inside the beads of hydrated polymer with greater surface of contact among roots, water and nutrients.

BUZETTO et al. (2002) assessed the efficacy of hydrogel application in planting $E$. urophylla. After nine months, the control (no hydrogel $+5 \mathrm{~L}$ water) showed $24.3 \%$ mortality, whereas the treatment with the addition 0,8 liter of solution ( $4 \mathrm{~g}$ of hydrogel dissolved in $5 \mathrm{~L}$ of water), had only $2.7 \%$ dead plants.

TABLE 2 - Average survival for treatments for seedlings of A. colubrina, L. cultratus, I. vera and P. guajava, 200 days after planting, depending on hardening and hydrogel application at planting.

\begin{tabular}{lllll}
\hline \multirow{2}{*}{ Specie } & \multicolumn{2}{l}{ Hardened seedlings } & \multicolumn{2}{l}{ Unhardened seedlings } \\
\cline { 2 - 5 } & $\begin{array}{l}\text { With } \\
\text { hydrogel }\end{array}$ & $\begin{array}{l}\text { Without } \\
\text { hydrogel }\end{array}$ & $\begin{array}{l}\text { With } \\
\text { hydrogel }\end{array}$ & $\begin{array}{l}\text { Without } \\
\text { hydrogel }\end{array}$ \\
\hline P. guajava & 91 & 91 & 91 & 96 \\
A. colubrina & 86 & 91 & 100 & 85 \\
I. vera & 95 & 100 & 100 & 100 \\
L. cultratus & 95 & 81 & 91 & 95 \\
\hline
\end{tabular}

\section{CONCLUSIONS}

In adding hydrogel at the planting hole of four forest species seedlings contributed to reducing the number of necessary irrigation.

Unhardening seedlings demanded smaller number of irrigations than hardened seedlings, in general.

According to the way the treatments were conducted, with different number of irrigations in function of the treatment, there were no differences in steam diameter and survival of seedlings in the field.

\section{REFERENCES}

ADAMS, J. C.; LOCKABY, B. G. Commercially produced super absorbent material increase water - holding capacity of soil medium. Tree-Planters, v.38, n. 1, p.24-25, 1987.

ALVARES, C. A.; STAPE, J. L.; SENTELHAS, P. C.; GONCALVEZ, J. L. M.; SPAROVEK, G. Köppen's climate classification map for Brazil. Meteorologische Zeitschrift, v. 22, n. 6, p. 711-728, 2013. Disponível em: < http://dx.doi.org/10.1127/0941-2948/2013/0507>. doi: 10.1127/09412948/2013/0507.

AZEVEDO, G. T. O. S.; AZEVEDO, G. B.; SOUZA, A. M.; MEWS, C. L.; SOUSA, J. L.R. Effect of hydrogel doses in the quality of Corymbia citriodora Hill \& Johnson seedlings. Nativa, v.4, n.4, p.244-248, 2016. Disponível em: < http://dx.doi.org/10.14583/2318-7670.v04n04a10>. doi: 10.14583/2318- 
7670.v04n04a10.

BARBOSA, T. C.; RODRIGUES, R. R.; COUTO, H. T. Z. Tamanhos de recipientes e o uso de hidrogel no estabelecimento de mudas de espécies florestais nativas. Hoehnea, v.40, n.3, 2013.

BUZETTO, F. A.; BIZON, J. M. C.; SEIXAS, F. Avaliação de polímero adsorvente à base de acrilamida no fornecimento de água para mudas de Eucalyptus urophylla em pós-plantio. Circular Técnica IPEF, n. 195, p.1-8, 2002.

D'AVILA, F. S.; PAVA, H. N.; LEITE, H. G.; BARROS, N. F.; LEITE, F. P. Efeito do potássio na fase de rustificaçao de mudas de eucalipto. Revista Árvore, v. 35, n. 1, p. 13-19, 2011. Disponível em: < http://dx.doi.org/10.1590/S010067622011000100002>. doi: 10.1590/S0100-67622011000100002.

DiAs-Terceiro, R. G.; PeIXOtO, G. M.; PESSOA, T. S. A.; NECO, E. C. Influencia de variáveis ambientais sobre a densidade de plântulas arbustivas e arbóreas em floresta de terra firme na Amazonia Oriental. Biotemas, v.27, n.3, p.191-195, 2014. Disponível em: <http://dx.doi.org/10.5007/21757925.2014v27n3p191>. doi: 10.5007/2175-7925.2014v27n3p191.

DRANSK, J. A.L.; PINTO JUNIOR, A. S.; CAMPAGNOLO, M. A.; MALAVASSI, U. C.; MALAVASSI, M. M. Sobrevivência e crescimento do pinhão-manso em função do método de aplicação e formulações de hidrogel. Revista Brasileira de Engenharia Agrícola e Ambiental, v.17, n.5, p.537-542, 2013. Disponível em: < http://dx.doi.org/10.1590/S1415-43662013000500011>. doi: 10.1590/S141543662013000500011.

EVANS. R.Y.; BOWMAN, D.C. Calcium inhibition of polyacrylamide gel hydration is partially reversible by potassium. Hort Science, v.26, n.8, p.1063-1065, 1991.

FELIPPE, D.; NAVROSKI, N. C.; SAMPIETRO, J. A.; FRIGOTTO, T.; ALBUQUERQUE, J. A.; MOTA, C. S.; PEREIRA, M. O. Efeito do hidrogel no crescimento de mudas de Eucalyptus benthamii submetidas a diferentes frequências de irrigação. Floresta, v.46, n.2, p.215-225, 2016. Disponível em: < http://dx.doi.org/10.5380/rf.v46i2.43920>. doi: 10.5380/rf.v46i2.43920.

FREITAS, T. A. S. D.; BARROSO, D. G.; CARNEIRO, J. G. D. A.; PENCHEL, R. M.; LAMÔNICA, K. R.; FERREIRA, D. D. A. Desempenho radicular de mudas de eucalipto produzidas em diferentes recipientes e substratos. Revista Árvore, v.29, n.6, p 853-861, 2005. Disponível em: < http://dx.doi.org/10.1590/S010067622005000600003>. doi: 10.1590/S0100-67622005000600003.

FRÓES, C. Q.; FIGUEIREDO, F. G.; LINE, J. D. B.; FERNANDES, S. S.; PADOVAN, M. P.; PEREIRA, Z. V. Desenvolvimento Inicial de Espécies Arbóreas de Diferentes Estágios Sucessionais em Campo para fins de Restauração Ecológica. Cadernos de Agroecologia,v.9, n.4, 2014. 
GAGETTI, B. L.; PIRATELLI, A. J.; PIÑA-RODRIGUES, F.C. M. Fruit color preference by birds and applications to ecological restoration. Brazilian Journal of Biology, v.76, n.4, 2016. Disponível em: <http://dx.doi.org/10.1590/15196984.05115>. doi: 10.1590/1519-6984.05115.

GOÉS, L. G.; QUINTELA, M. F. Florística e estrutura de um reflorestamento no maciço da tijuca, Rio de Janeiro, RJ, Brasil. Revista Internacional de Ciências, v.5, n.1, 2015. Disponível em: <http://dx.doi.org/10.12957/ric.2015.16690>. doi: 10.12957/ric.2015.16690.

GONÇALVES, J. L. M.; STAPE, J. L.; BENEDETTI, V. A. G. Reflexos do cultivo mínimo e intensivo do solo em sua fertilidade e na nutrição das árvores. In: GONÇALVES, J. L.; BENEDETTI, V. (Eds.). Nutrição e fertilização florestal. Piracicaba: IPEF, 2000. p. 3-57.

KRAG, M. N.; VALE, R. S.; SILVA, E.; OLIVERA, F. A.; GAMA, M. A. P.; SILVA, P. T. E. Avaliação qualitativa de impactos ambientais considerando as etapas de limpeza e preparo do terreno em plantios florestais no nordeste paraense. Revista Árvore, v.37, n.4, p.725-735, 2013. Disponível em: < http://dx.doi.org/10.1590/S010067622013000400016>. doi: 10.1590/S0100-67622013000400016.

KORTZ, A. R.; COELHO, S.; CASTELlO, A. C. D.; LeITE, A. C.; CORREIA, L. S.; $\mathrm{KOCH}, \mathrm{I}$. Wood vegetation in Atlantic rain forest remnants in Sorocaba (São Paulo, Brazil). Journal of species lists and distribution, v. 10, n. 2, p. 344-354, 2014.

LOPES, J. L. W.; SILVA, M. R.; SAAD, J. C. C.; ANGELICO, T. S. Uso de hidrogel na sobrevivência de mudas de Eucalyptus urograndis produzidas com diferentes substratos e manejos hídricos. Ciência Florestal, v.20, n.2, p.217-224, 2010. Disponível em: <http://dx.doi.org/10.5902/198050981847> doi: 10.5902/198050981847.

MAFIA, R. G.; ALFENAS, A. C.; SIQUEIRA, L.; FERREIRA, E. M.; LEITE, H. G.; CAVALLAZZI, J. R. P. Critério técnico para determinação da idade ótima de mudas de eucalipto para plantio. Revista Árvore, v.29, n.6, p.947-953, 2005. Disponível em: < http://dx.doi.org/10.1590/S0100-67622005000600014>. doi: 10.1590/S010067622005000600014.

MARQUES, P. A. A.; CRIPA, M. A. M.; MARTINEZ, E. H. Hidrogel como substituto da irrigação complementar em viveiro telado de mudas de cafeeiro. Ciência Rural, v.43, n.1, 2013. Disponível em: <http://dx.doi.org/10.1590/S010384782012005000129>. doi: 10.1590/S0103-84782012005000129.

MAZZUCHELLI, E. H. L.; SOUZA, G. M.; PACHECO, A. C. Rustificação de mudas de eucalipto via aplicação de ácido salicílico. Pesquisa Agropecuaria Tropical, v. 44, n. 4, p 443-450, 2014. 
MEWS, C. L.; SOUZA, J. L. R., AZEVEDO, G. T. O. S., SOUZA, A. M. Efeito do Hidrogel e Ureia na Produção de Mudas de Handroanthus ochraceus (Cham.) Mattos. Floresta e Ambiente, v.22, n.1, p.107-116, 2015. Disponível em: <http://dx.doi.org/10.1590/2179-8087.080814>. doi: 10.1590/2179-8087.080814.

MONTESANO, F. F.; PARENTE, A.; SANTAMARIA, P.; SANNINO, A.; SERIO, F. Biodegradable Superabsorbent Hydrogel IncreasesWater Retention Properties of Growing Media and Plant Growth. Agriculture and Agricultural Science Procedia, v.4, p.451-458, 2015. Disponível em: <http://dx.doi.org/10.1016/j.aaspro.2015.03.052>. doi: 10.1016/j.aaspro.2015.03.052.

NAVROSKI, M. C.; ARAÚJO, M. M.; CUNHA, F. S.; BERGHETTI, A. L. P.; PEREIRA, M. O. Influência do polímero hidroretentor na sobrevivência de mudas de Eucalyptus dunnii sob diferentes manejos hídricos. Revista Nativa, v.2, n.2, p.108 113, 2014. Disponível em: < http://dx.doi.org/10.14583/2318-7670.v02n02a08>. doi: 10.14583/2318-7670.v02n02a08.

NAVROSKI, M. C.; ARAUJO, M. M.; PEREIRA, M. O.; FIOR, C. S. Influência do polímero hidroretentor nas características do substrato comercial para produção de mudas florestais. Interciencia, v.41, n.5, 2016.

NICOLETTI, M. F; NAVROSKI, M. C.; ANDRIOLLO, K.; PEREIRA, M. O.; FRIGOTTO, T. Efeito do hidrogel no enraizamento e crescimento inicial de miniestaca do híbrido Eucalyptus urograndis. Cultivando o Saber, v.7, n.4, p.353 361, 2014.

NISSEN, M. J.; OVANDO, C. Efecto de um hidrogel humectado aplicado a las raices de Nothofagus obliqua (MIRB.) OERST. Y Nothofagm dombeyi (MIRB.) OERST. Durante su trasplante. Agro Sur, v.27, n.2, p.48-58, 1999.

NOGUEIRA JUNIOR, L. R.; ENGEL, V. L.; PARROTA, J. A.; MELO, A. C. G.; RÉ, D. $S$. Allometric equations for estimating tree biomass in restored mixed-species Atlantic Forest stands. Biota Neotropica, v.14, n.2, 2014. Disponível em: <http://dx.doi.org/10.1590/1676-06032013008413>. doi: 10.1590/167606032013008413.

RAMOS, B. Z.; PAIS, P. S. M.; FREITAS, W. A., DIAS JUNIOR, M. S. Avaliação dos atributos físico-hídricos em um Latossolo Vermelho distroférrico sob diferentes sistemas de manejo - Lavras/ Minas Gerais/ Brasil. Revista de Ciências Agrárias, v.36, n.3, 2013.

SILVEIRA, R. L. V. A.; MALAVOLTA, E. Nutrição e adubação potássica em Eucalyptus. Informações agronômicas, n.91, 2000.12p.

THOMAS, D.S. Hydrogel applied to the root plug of subtropical eucalypt seedlings halves transplant death following planting. Forest Ecology and Management, v.255, n.3-4, p.1305-1314, 2008. Disponível em: 
<http://dx.doi.org/10.1016/j.foreco.2007.10.035>. doi: 10.1016/j.foreco.2007.10.035.

WOFFORD JUNIOR, D. J.; KOSKI, A. J. A polymer for the drought years (on line). Colorado Green. 1990. Disponível em: http://kimberly.ars.usda.gov. Acesso em: 01/03/2015. 